\title{
Article
}

\section{The most 'undeserving' of all?: how poverty drives young men to victimisation and crime}

Kingston, Sarah and Webster, Colin

Available at http://clok.uclan.ac.uk/31286/

Kingston, Sarah ORCID: 0000-0002-9226-1915 and Webster, Colin (2015) The most 'undeserving' of all?: how poverty drives young men to victimisation and crime. Journal of Poverty and Social Justice, 23 (3). pp. 215-227. ISSN 17598273

It is advisable to refer to the publisher's version if you intend to cite from the work. http://dx.doi.org/10.1332/175982715X14448287452303

For more information about UCLan's research in this area go to http://www.uclan.ac.uk/researchgroups/ and search for <name of research Group>.

For information about Research generally at UCLan please go to http://www.uclan.ac.uk/research/

All outputs in CLoK are protected by Intellectual Property Rights law, including Copyright law. Copyright, IPR and Moral Rights for the works on this site are retained by the individual authors and/or other copyright owners. Terms and conditions for use of this material are defined in the policies page.

\section{CLoK}

Central Lancashire online Knowledge www.clok.uclan.ac.uk

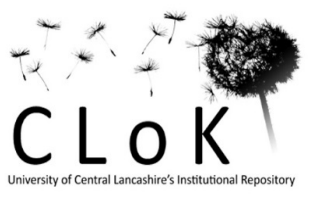




\title{
article
}

\section{The most 'undeserving' of all? How poverty drives young men to victimisation and crime}

\author{
Sarah Kingston, s.kingston@lancaster.ac.uk \\ Lancaster University, UK \\ Colin Webster, c.webster@leedsbeckett.ac.uk \\ Leeds Beckett University, UK
}

\begin{abstract}
Public policy reform over several decades has succeeded in systematically impoverishing and worsening the social and economic conditions of poor, single young men. That this group is the most prone to criminality and criminalisation, while being pushed further into the margins of the licit and illicit economy, has been a central feature of long-term and growing crime trends. The article argues that successive governments have been unwise to neglect the poverty of unemployed, single young men into young adulthood. Their comparatively unfavourable treatment (as the most 'undeserving' of the 'undeserving poor') has impoverished a group renowned for being crime-prone.
\end{abstract}

key words poverty $\cdot$ youth

\section{Introduction}

Links between poverty and crime are strengthened by early experiences of childhood poverty, and the rapidity and intensity of poverty experiences, and whether these experiences are prolonged or short lived. Living in poverty makes offending and being the victim of a property or violent crime much more likely. And yet, education, welfare, housing and labour market reforms over decades have systematically worsened the social and economic conditions of poor, single young men. Impoverishing a group already prone to criminality and criminalisation, reforms have pushed young men into the margins of the licit and illicit economy, further marginalising them. Their impoverishment and marginalisation has been a central feature of long-term and growing crime trends.

Modest improvements in their employment situation since the mid-1990s, followed by relatively muted poverty increases in the post-2008 recession, compared to previous recessions, partly ensured that crime continued to decline. Subsequent austerity policies have again marginalised this group. Since the 2008 recession, young single men living in poor areas have seen the most rising levels of hardship. The article argues that successive governments have been unwise to neglect the poverty of unemployed and underemployed single young men into young adulthood. Their comparatively unfavourable treatment (as the most 'undeserving' of the 'undeserving poor') has 
impoverished a group renowned for being crime-prone, making it more likely they find 'solutions' to their poverty in crime.

The article furthers conclusions from our comprehensive review of the evidence about the impact of poverty on crime commissioned by the Joseph Rowntree Foundation (Webster and Kingston, 2014a). A repeated pattern emerged from this review that pointed to the poverty effects on working-class young people of longterm policy changes in welfare, housing and employment. This relationship between growing youth poverty and policy took a turn for the worse with growing youth unemployment from the 1970s. We believe that the history of this relationship in Britain shows an adverse and cumulative effect from 1980 to the present.

The article argues from this broad approach that the worsening of young people's social conditions resulted from their cumulative and systematic impoverishment over the whole period. In profoundly changing their routes to independence poor young men's criminal involvement was inadvertently hastened and encouraged. The article asks why then, if poverty and crime rates among poor young men are so aligned, has crime continued to decline in the recent period while poverty increased after the 2008 recession. The article concludes with a discussion about the prospects of poor young men and their involvement in crime under 'austerity'. The considerable ground covered, reflects the article's origins in a wide-ranging historical review of evidence linking poverty and crime, and the strengthening of this relationship found over time for some groups of young men. Overall, in cataloguing increasingly punitive welfare and work policies targeting poor young men, policy is revealed to be malign.

\section{The evidence linking poverty and crime}

Sometimes popular and academic parlance agree that those who live in poverty are more likely to be the victim of crime and offend. After all, in Britain the majority of those arrested and imprisoned have experienced poverty. At other times thinking has strongly contested the idea that poverty alone in some straightforward way causes crime on the basis that most poor people are law abiding and eschew law breaking. We reviewed the academic research delineating the nature of the supposed relationship between poverty and crime, the mechanisms involved and the groups effected. From this we concluded that although the relationship between poverty and crime is not always direct, living in poverty makes offending and being the victim of crime much more likely. We were struck by how regularly the most crime prone group are poor single young men. Despite their susceptibility to crime we were also struck by their worsening conditions and impoverishment as a group over much of the last 35 years (Webster and Kingston, 2014a; 2014b). As economic recessions became more frequent, youth poverty and unemployment grew in intensity and duration. The growing research interest in the impact of poverty on crime was able to capture, with the benefit of hindsight and the application of longitudinal perspectives, hitherto unknown levels, longevity and concentrations of poverty and crime relationships. Studies of this relationship occurring among cohorts who had experienced poverty while growing up in earlier periods tended to conclude that the impact of poverty on crime was weaker than studies conducted over later periods. There was something about the quantity and quality of poverty experiences that had changed leading to the likelihood of more adverse, anti-social poverty outcomes such as delinquency and crime. 
Earlier studies of the impact of poverty on crime among children and young adults growing up before the onset of mass youth unemployment usually found an inconclusive or weak relationship between poverty and crime (Tittle and Meier, 1990; Sampson and Laub, 1993; Wright et al, 1999; Tittle et al, 1978; Tittle, 1983; Rutter and Giller, 1983). The first studies to capture the emergence of mass youth unemployment and poverty during the 1980s and early 1990s, found that violent and property crime were associated with absolute and relative poverty and economic inequality (Kawachi et al, 1999; Kennedy et al, 1998; Messner, 1989). These studies were more likely to find a strong and direct relationship between poverty and offending, particularly the impact of childhood poverty and the effects of growing up poor on later persistent youth offending (Braithwaite, 1981; Jarjoura et al, 2002; Hay and Forrest, 2009; Bjerk, 2007).

Longitudinal approaches followed children growing up in poverty finding that adverse family, individual, school and peer factors, associated with poverty, increased individual susceptibility to crime. The longer a young person lives in poverty the more likely they are to engage in delinquent behaviour (Fergusson et al, 2004; Wright et al, 1999; Jarjoura et al, 2002). It is the longevity and recurrence of poverty that adversely influences family processes causing disruption and emotional stress. Long-term poverty influences the resources and therefore opportunities available to children and young people and their emotional security, and has the strongest impact on criminal involvement (Skardhamar, 2009; Bottoms et al, 2004). Crises of unemployment during economic recessions polarises the poor into offenders and non-offenders, felt most severely by those with the lowest level of resources and the most structural constraints due to their criminal involvement (Nilsson et al, 2013; Verbruggen et al, 2012; Hallsten et al, 2013; Bottoms et al, 2004). Finally, economic recession and mass unemployment concentrate crime spatially. For example, 42 per cent of all burglaries happen to 1 per cent of all homes principally those belonging to the poor and/or single parents (Budd, 2001). Poverty remains the most important and direct influence on neighbourhood violent crime, and poverty rather than neighbourhood cohesion has the strongest relationship with crime rates (Hooghe et al, 2011; Bruinsma et al, 2013; Sutherland et al, 2013). Indeed the most striking and consistent relationship between poverty and crime across many different settings is that poverty predicts area homicide rates (Pridemore, 2011).

\section{Impoverishing young men}

The growing interest in the impact of poverty on crime emerged around 1980 at a time of unprecedented increases in poverty and unemployment, accompanied by steep rises in the crime rate. As we have seen, studies were more interested in whether unemployment and poverty caused or correlated with crime in a general sense, rather than with identifying the particular social groups effected. In Britain, youth unemployment in 1980 rose more than it had in the previous ten years put together (MacDonald, 2011). Of course the coincidence of rises in poverty and crime did not mean they were necessarily linked.After all, the quadrupling of crime between 1957 and 1977, occurred before the rise of discernible large-scale youth unemployment occasioned by the economic recessions of 1978-84 (Willis et al, 1988; Tombs, 2014). There were, though, some striking historical markers in long-term trends in youth wages, welfare and crime. While the 1950s recorded some of the lowest levels of 
recorded crime in Britain's history, over this period the wages of the young rose 83 per cent. Pockets of 'forgotten' poverty certainly existed from the 1950s to the 1970s, yet it is instructive that Unemployment Benefit rose in real value from 1948 to 1978 , then very significantly declined in real value from 1978 to 2008 (Atkinson, 2015). In the past, Unemployment Benefit (now Jobseeker's Allowance), has been a mainstay of survival for single young men without children suffering the hardships of unemployment. ${ }^{1}$

It would be wrong to think of the period before 1980 as a 'golden age' for working class young people's transitions from school into the labour market. Before 198035 per cent of male school-leavers went into apprenticeships, youth wages were still protected by Wages Councils, and a semblance of youth welfare protections still existed. But not all was well. It was a time of crises in youth unemployment and growing youth crime (Hall et al, 1978;Vickerstaffe, 2003). It would be equally wrong to bracket all young men together under some generic age and 'masculinity' as the basis to explain poverty and crime. Reflecting on Thatcher's legacy, Dorling (2014) reminds us that a young man brought up in relative affluence outside the urban cores of the North, Wales, Scotland or Northern Ireland, might have thought that the 1980s and 1990s had been a great economic success, especially if the place of their upbringing was London and the South East. To lose sight of these different experiences of young men according to their time, place and class ignores the specificity of the experiences and position of poor young men (Grover, 2008). Relationships between the wider economy, poverty and youth crime are not straightforward.

The widespread and systematic impoverishment of working-class young people, abetted by work and welfare reforms, was first felt in areas of traditional industry. Willis et al's (1988) close-up study of the social experiences and economic conditions faced by young workers in Wolverhampton in 1983 and 1984 set the stage and gave a focus to the growing effects of work and welfare changes on youth and young adult poverty over the next decade. The experiences and conditions described then became defining features of young people's subsequent transitions from the 1980s to the present, as do the policy responses to youth poverty. At the time of the study a third of 16-24 year olds living in Wolverhampton had no work, most had been unemployed for more than six months, and some would never work again. About a third of Wolverhampton's young people were living in poverty. It is around this time and in these sorts of places that the welfare assault on, and impoverishment of, poor young people began. Young people aged 18 to 20 who lived at home were the victims of the first cash cut in Social Security Benefit since the Welfare State began. Much worse was to follow over the course of the 1980s. The Wolverhampton Study (Willis, 1988, xix), based on a survey and interviews with young people, concluded,

There are a few 'deserving' poor and they have to be helped. But there is something else in mind for the 'undeserving' poor - which certainly includes the young unemployed.They must be forced into work motivation and work discipline and be made accustomed to poverty level pay in order to supply the ready, cheap workforce necessary for local economic revival. Recipients of welfare must be willing to demonstrate their moral fibre (work readiness) by undertaking some make work job or apparent training in order to receive their 'pay'. 
Coercive measures targeted the young unemployed seen in the withdrawal of benefit for all under 18s; a compulsion to attend Youth Training for two years; the lowering of Benefit rates for the under 25s and the withdrawal of special payments; the drastic curtailment of rent and rate rebates; compulsory six-monthly job interviews for the unemployed with loss of benefit for those not attending; and the removal of the right to attend Further Education for up to 21 hours without losing benefit. All these reforms deliberately aimed to impoverish unemployed young men. Blame for growing youth poverty was placed on the failure of their families to support them (Walker, 2014). By lowering their income support and raising their contributions to family rent costs, independent living for this group became difficult if not impossible (Hill and Walker, 2014). Until 1985 youth poverty was the result of an explosion in youth unemployment. After 1985 youth poverty and homelessness was due largely to government policies and 1987 saw the start of more radical changes (Hill and Walker, 2014; Farrall and Jennings, 2014). Earlier losses of income support and housing benefits for 16- and 17-year-old claimants, and reductions for 18-24-year-olds, were compounded by the 1988 Social Security Act, which increased homelessness among those aged 16-18, and corralled poor young people together in 'sink estates' (Carlen, 1996; Farrall and Jennings, 2014).When Unemployment Benefit was re-titled Jobseeker's Allowance in 1995, the rate was lowered again for those aged under 25 years. Difficulties were particularly sharp where their families of origin do not have the financial means to support young adults or they are estranged from their families. These conditions are particularly likely to occur among those with a significant history of adolescent offending, who will inevitably often find themselves looking for accommodation in the shrinking 'social housing' sector (Farrall et al, 2010).

\section{Poor young men's changing routes to independence}

As family poverty increased from the beginning of 1980 and children were more likely to be living in poor households - by 1997, 25 per cent of households were living in poverty - cohort studies show that childhood poverty became even more strongly associated with low-paid work and unemployment later (Jones, 2002).Young people's lives have irrevocably changed over the past 35 years. Comparing those reaching the age of 25 in 1983 and those reaching this age in 1995, youth poverty has worsened and a widening gap has opened between the unqualified and qualified, polarising young people, compared to the experiences of young people born in the 1960s.

British young people born in 1958 struggled to emerge from recession in the early 1980s. Those born in 1970, however, had come through a second recession in 1995 to find their prospects dramatically altered, separating these two groups. Comparing the two groups of young people between the ages of 16 and 26, well over half the young people born in 1958 left school at the minimum age in 1974, mostly moving into jobs and apprenticeships. By 1986, the youth labour market in many parts of the country had collapsed, and school leavers faced a mixture of youth training schemes, casual jobs or unemployment. Experience of poverty as a child had a greater adverse influence on the earnings of young adults born in 1970 than those born in 1958. The relatively secure niches in jobs or apprenticeships that still existed for schoolleavers in the mid-1970s had disappeared by the mid-1980s, leading to a less assured position in the adult labour market. Those born in poor households in 1970 were much more likely to be unemployed or out of the labour force in their early 20 s, or 
to be found more frequently in low-paid jobs. Even when education was taken into account a penalty attached to poverty in childhood remained and increased over time (Bynner et al, 2002). Early school-leavers have been marginalised as traditional craft apprenticeships for young men have been largely replaced by service sector occupations (hospitality, catering and caring) often part-time and on relatively low pay.They are worse off and comparably poorer compared with the situation of young people 25 years earlier. In addition, the earnings of young people, relative to those aged over 25 years, have declined dramatically over the period (Bynner et al, 2002).

\section{Why has crime declined while poverty increased?}

We have established that unemployment and poverty is positively and strongly associated with the rate of acquisitive crime in Britain, and elsewhere, and that virtually all recent studies find a strong relationship between dramatic increases in inequality, poverty and violent crime. Previous recessions such as those that occurred during the 1980s and early 1990s saw dramatic if delayed increases in crime and the impact of unemployment and poverty on rises in crime rates. The 2008 recession is different. This time around there have been far fewer lost jobs than there were in the recessions of the 1980s and 1990s, with something like half of the fall in employment seen in the 1990s. More important still, it was the lengths of very high unemployment rates for a decade in the downturns of the 1980s and 1990s that differentiates then and now (Clarke and Heath, 2014). It is the duration and the depth (as well as the rapidity with which it occurs) of unemployment and associated poverty that probably accounts for the greater impact of poverty on crime. In the downturn begun in 2008 we have seen a less dramatic effect on employment rates and the beginnings of improvement only five years on.

We argue, in fact, that the recent divergence between continuing and dramatic drops in property and especially violent crime, and rising levels of poverty resulting from the 2008 financial crisis, actually supports and strengthens an established link between poverty and crime. It should be remembered that this recession is different to previous recessions, in that unemployment peaked at the end of 2011 at 2.7 million, and fell to 2.5 million in 2013. The question now is the nature and quality of this new employment (Lanchester, 2013). Of course, these effects are strikingly variable across places and in the sorts of jobs that have become available, with some localities returning to 1990s levels of unemployment, and many of the new jobs are part-time, low waged and insecure. The gradual cumulative disadvantage over decades seen in deindustrialisation from the 1960s and 1970s, is compounded by what happens every time downturns occur. Whenever conditions in the jobs market worsen, unemployment rises further and faster for the less qualified, early school leavers, the less skilled, young people, ethnic minorities, men and those living in certain regions or areas. Each recession hits these groups harder and from which they can find it more difficult to recover. One might have expected the poverty and crime link to be particularly strengthened in the 2008 recession when one considers that in each successive recession since the 1970s, British youth unemployment has exceeded 20 per cent (Clarke and Heath, 2014).

The differences are that poor children are now twice as likely to come from a working home than from a home without work, individuals have not remained unemployed once recovery came, relative poverty in Britain actually fell through 
the initial stages of the 2008 recession because of plunging average incomes, and absolute poverty in Britain remained stable compared to any other major western country, in part because of Britain's system of family tax credits (Clarke and Heath, 2014). It was only after 2010 and with the arrival of the coalition's 'austerity' policies that conditions for the poor became much harder (see Schui, 2014; Blyth, 2013). Finally, the inextricable thread linking policy towards youth poverty over the past 35 years is still the problem of youth unemployment. There has, however, been a shift from the centrality of youth unemployment to young people experiencing underemployment (MacDonald, 2011). This refocuses attention on how poor young men not in education, employment or training (NEET), can churn between insecure low level jobs and unemployment over the long term. Significantly, the number of underemployed men has increased by over a half during the 2008 UK recession and, significantly, one in five of the underemployed are aged between 16 and 24 .

\section{Poor young men and crime under 'austerity'}

Those aged 16-24 have fared particularly badly since the 2008 recession having faced the highest rates of unemployment, redundancy and decline in employment. There are 1.7 million young people aged 16-24 living in 'low-income' households and, of these, 1.1 million are single adults without children - a much greater proportion than for older age groups. Since the mid-1990s one third of 16-24 year-olds have suffered poverty compared to a fifth of older working age adults. The 2008 recession exacerbated the growth to more than one in every seven or a million NEET 16-24 year olds in England. More young people have no experience of paid work. Although the NEET group is diverse and dynamic in the routes by which they become, stay or leave their NEET status, poor young men face particular difficulties accessing and maintaining employment. Change to more work in service sector employment that employ large numbers of young people such as retail, leisure and hospitality, requires the sorts of 'soft skills' and 'job-ready' performance that are less developed among poor young men, who in any case increasingly compete for the same types of jobs as young women (Sissons and Jones, 2012).

The transition from Labour to the coalition government continued to discipline poor young people to accept low-paid, insecure work and unemployment thereby entrenching their poverty and disadvantage (Melrose, 2012). Labour's New Deal for Young People (NDYP) paved the way by extending the element of compulsion introduced by the Conservative's Job Seekers' allowance in the 1980s. The penalties and sanctions placed on claimants aged under 25 years old for refusing 'to take up opportunities' were increased in severity with each failure to comply by the coalition's Welfare Reform Bill (2011). Why were a disproportionate share of these sanctions levied on the under-25s and why have sanctions grown in number? (MacInnes et al, 2013). While under Labour, participation in NDYP was made compulsory for 18-24 year olds who had been unemployed for six months or more, the coalition withdrew the Future Jobs Fund, increasing the chance that young people aged 16-24 will be NEET. Labour introduced Education Maintenance Allowances (EMAs) in 2004 , aimed at the children of poor families whose participation rates in post-16 education were particularly low. EMAs offered payments of up to $£ 40$ per week to stay in education past the age of 16 and were particularly successful in encouraging poor boys living in urban areas to stay. Evaluations concluded that the largest impact 
improving the destinations of young people was on poor families and young men (Coles, 2011). The coalition government abolished the EMAs on coming to power in 2010, and withdrew support for more than 100,000 poor 18-25 year olds who had been unemployed for over six months, guaranteeing them new jobs paying at least national minimum wage (Coles, 2011). This - the Young Persons Guarantee and Future Jobs Fund - introduced in 2009, aimed at helping young people to escape the impact of the 2008 recession was judged successful. Why, then, were EMAs and the Future Jobs Fund aimed at alleviating the social and economic conditions of poor young men withdrawn?

According to MacInnes et al (2014) male earnings have fallen most between 2008 and 2013 and there has been an increase in the proportion of men who are low paid as male pay has fallen. Although unemployment is now falling quickly for young adults, 18 per cent of adults aged 16-24 were unemployed, compared with 5 per cent of aged 25 and over in 2014. Young adult unemployment has been substantially higher than older adult unemployment throughout the entire period, 1992-2014. Although the young adult unemployment rate has fallen quickly recently, it remains substantially higher than for older adults. The most striking trend over this period has been a halving of the poverty rate for lone parents, due to a steep rise in the lone parent employment rate over this period, along with the introduction of tax credits. Contrastingly, over the same period 16-29-year-olds were the only group to see an increase in its poverty rate. Young adults (16-24) make up 40 per cent of the unemployed, despite being just 17 per cent of the working-age population. Their share of total unemployment rose steadily from the early 1990s, reaching a peak in 2008 of 45 per cent. Around one in eight under-25s is now unemployed - at least twice the rate of any other age group (Kenway et al, 2015).

Initially, as a result of decisions made under Labour, the poor were protected during the coalition's first two years up to 2012-13 at a time when real earnings fell during the recession. There will already have been a sharp rise in relative poverty between 2012/13 and 2014/15 for children and for working-age non-parents, and then a further rise to $2020 / 21$, with the relative child poverty rate reaching 21 per cent, up 3.5 percentage points from 2012/13. There will continue to be stricter administration of many out-of-work benefits, including much greater use of 'sanctions' imposed on unemployed and other claimants for not meeting particular job-search requirements (Hills, 2015). Meanwhile, the recently elected Conservative government still faces a weak system of apprenticeships for young people and relatively ineffective mechanisms for helping workless people back into work. We saw how the coalition's supply side measures in the labour market represented evolution rather than revolution. Labour's 'welfare to work' programme was reformed, but the aims remained similar (McKnight and Hills, 2015).

Overall, work, welfare and criminal justice policies that fall particularly harshly upon poor young men have required them to behave in a certain way to access welfare cash benefits, housing or support services. Enforced through penalties or 'sanctions' that reduce, suspend or end access to these goods, behavioural requirements are now used much more frequently, and their severity has increased, particularly in respect of out-of-work-benefits. Benefit sanctions are having a strongly disproportionate effect on poor young people under 25, and there is also evidence of severe impacts on homeless people and other vulnerable groups. This enlargement of the scope and range of behaviours covered, particularly in relation to anti-social behaviour (ASB), 
social housing and homelessness, has led Watts et al (2014) to conclude that any benefits in terms of improvements to street-based lifestyles and ASB, may be offset by the hardship faced by those failing to meet behavioural conditions.

While the Labour government's tax and benefit reforms and policies towards poverty since 1997 reduced child poverty and benefited parents with children, poverty rates for working-age adults without children had reached record levels by 2002/03 (Hills and Stewart, 2004). Meanwhile poor young people today face the same difficulties finding employment as they experienced in the past.The continuities with the past are perhaps most clearly seen in the Prime Minister's proposal to remove entitlement to housing benefit for all people aged 16-24, subsequently amending this for unemployed people aged 18 to 21 only, inevitably increasing poverty and homelessness for this group. Similarly, at the time of writing, the current Conservative government is to make sure that unemployed 18-21-year-olds will have to claim a youth allowance under the Full Employment and Welfare Benefits Bill, with strict conditionality. After six months, they will have to start an apprenticeship or training to continue to receive money. As MacDonald (2011) has argued in respect of policy towards the problem of youth unemployment and underemployment since 1980, 'Plus ça change, plus c'est la même chose'. The young in general, and this group in particular, now face the most precarious future as youth unemployment rose at twice the average rate through the financial crisis and during 2014 stood at three times the national average. In 2014 some 950,000 young people aged 16-24 were not only unemployed but also not in education or training (Lansley and Mack, 2015).

\section{Discussion and conclusion}

Begun around 1980 reforms over 35 years in the areas of education and training, welfare, housing and the labour market policy have had consistently and systematically adverse effects on single teenage and young adult men without children living in poor areas. As worrying levels of youth unemployment began to appear after 1977 this group occupied places and times where crime and murder rates more than doubled, unemployment soared and 'poverty drugs' became endemic (Thompson, 2014; MacDonald and Marsh, 2005).Turning to poor, young, childless, working-class men, policy and popular fears have engendered the group as the most undeserving of the poor. Of course, other social groups have suffered disproportionate poverty too - and the sort of vilification reserved for poor young men - most notably lone parents (Hills and Stewart, 2004). It is the relentlessness with which poor young men have seen their poverty worsen and its alleviation fade over 35 years that is striking. In worsening poor young men's social and economic conditions, policies have exposed them to criminal temptations and opportunities that might otherwise not have existed. Instead of preventing and alleviating their poverty, policies have hastened and deepened it. In this sense they are the most 'undeserving' and 'punished' of the able-bodied poor (Wacquant, 2009).

Long-standing policies towards alleviating poverty have focused on pensioners, lone parents and couples with children, particularly the children of the working poor.The living standards of families with children - both couples and lone parents - were protected in part by the subdued effects of the 2008 recession on making families entirely workless, but also because of increases to tax credits at that time among those remaining in work. The group seeing the most dramatic rises in poverty and 
worklessness during the period were young single adults without children, living alone (Schmuecker, 2013; Padley and Hirsch, 2013). Since the 2008 recession, young single men living in poor areas have suffered the most and rising hardship. Whether this presages rises in the crime rate seen in previous recessions remains to be seen.

\section{Note}

${ }^{1}$ According to TUC estimates, over the long term, Unemployment Benefits for all groups have declined. If Jobseeker's Allowance (JSA) had been increased in line with earnings over the previous 30 years, the rate for a single person over 25 years of age would have been $\mathcal{K}_{113.26}$ in 2007 , as opposed to $\mathcal{K}^{59}$.15. Increasing JSA in line with earnings just since 1997 would have meant payment of $£ 75$ a week in 2007. Single people aged 25 and under have seen the largest and fastest decline in the real values of their benefits over time. In 1999, the minimum income needed for healthy living by a single working man aged 18-30 in the UK was estimated at $\mathcal{1} 131.86$ per week. At the time, the relevant rates of Income Support and Jobseeker's Allowance were $\mathcal{E}^{40.70}$ for young people and $£ 51.40$ for over 25s. More recently, a single person in the UK needed to earn at least $£ 14,400$ a year before tax in 2010, to afford a basic but acceptable standard of living. And yet a single person who in 2000 could afford a minimum basket of goods and services, would be $\mathcal{K}^{19}$ a week short of being able to afford the same basket in 2010 - a fall in living standard of over 10 per cent (TUC, 2013).

\section{References}

Atkinson, AB, 2015, Inequality: What can be done?, London: Harvard University Press Bjerk, D, 2007, Measuring the relationship between youth criminal participation and household economic resources, Journal of Quantitative Criminology 23, 23-39

Blyth, M, 2013, Austerity: The history of a dangerous idea, Oxford: Oxford University Press Bottoms, A, Shapland, J, Costello, A, Holmes, D, Muir, G, 2004, Towards desistance: Theoretical underpinnings for an empirical study, The Howard Journal 43, 4, 368-89 Braithwaite, J, 1981, The myth of social class and criminality reconsidered, American Sociological Review 46, 1, 36-57

Bruinsma, GJN, Pauwels, LJR, Weerman, FM, Bernasco,W, 2013, Social disorganization, social capital, collective efficacy and the spatial distribution of crime and offenders: An empirical test of six neighbourhood models for a Dutch city, British Journal of Criminology 53, 5, 942-63

Budd, T, 2001, Burglary: Practice messages from The British Crime Survey, Briefing Note 5/01, London: Home Office.

Bynner, J, Elias, P, McKnight, A, Pan, H, Pierre, G, 2002, Young people's changing routes to independence, York: Joseph Rowntree Foundation

Carlen, P, 1996, Jigsaw: Political criminology of youth homelessness, Maidenhead: Open University Press

Clark, T, Heath, A, 2014, Hard times: The divisive toll of the economic slump, London:Yale University Press

Coles, B, 2011, Youth, in N Yeates, R Haux, M Jawad, M Kilkey (eds) In defence of welfare: The impacts of the spending review, social-policy.org.uk/downloads/idow.pdf

Dorling, D, 2014, Mapping the Thatcherite legacy: The human geography of social inequality in Britain since the 1970s, in S Farrall, C Hay (eds) The legacy of Thatcherism: Assessing and exploring Thatcherite social and economic policies, Oxford: Oxford University Press and the British Academy 
Farrall, S, Hay, C, 2010, Not so tough on crime? Why weren't the Thatcher governments more radical in reforming the criminal justice system?, British Journal of Criminology 50, 550-69

Farrall, S, Bottoms, A, Shapland, J, 2010, Social structures and desistance from crime, European Journal of Criminology, 7,6, 546-70

Farrall, S, Jennings, W, 2014, Thatcherism and crime:The beast that never roared?, in S Farrall, C Hay, C (eds) The legacy of Thatcherism: Assessing and exploring Thatcherite social and economic policies, Oxford: Oxford University Press and the British Academy

Fergusson, D, Swain-Campbell, N, Horwood,J, 2004, How does childhood economic disadvantage lead to crime?, Journal of Child Psychology and Psychiatry 45, 956-66

Grover, C, 2008, Crime and inequality, Cullompton: Willan

Hall, S, Critcher, C, Jefferson, T, Clarke, J, Roberts, B, 1978, Policing the crisis: Mugging, the state, and law and order, London: Macmillan

Hallsten, M, Szulkin, R, Sarnecki, J, 2013, Crime as a price of inequality? The gap in registered crime between childhood immigrants, children of immigrants and children of native Swedes, British Journal of Criminology 53, 3, 456-81

Hay, C, Forrest,W, 2009, The implications of family poverty for a pattern of persistent offending, J Savage (ed) The development of persistent criminality, Oxford: Oxford University Press

Hill, M, Walker, A, 2014, What were the lasting effects of Thatcher's legacy for social security? The burial of Beveridge?, in S Farrall, C Hay (eds) The legacy of Thatcherism: Assessing and exploring Thatcherite social and economic policies, Oxford: Oxford University Press and the British Academy

Hills, J, 2015, The coalition's record on cash transfers, poverty and inequality 20102015, CASE, Summary Working paper 11, http://sticerd.lse.ac.uk/dps/case/spcc/ WP11.pdf

Hills, J, Stewart, K (eds), 2004, A more equal society? New Labour, poverty, inequality and exclusion, Bristol: The Policy Press

Hooghe, M, Vanhoutte, B, Hardyns, W, Bircan, T, 2011, Unemployment, inequality, poverty and crime: Spatial distribution patterns of criminal acts in Belgium 2001-6, British Journal of Criminology 51, 1, 1-20

Jarjoura, GR, Triplett, RA, Brinker, GP, 2002, Growing up poor: Examining the link between persistent childhood poverty and delinquency, Journal of Quantitative Criminology 18: 159-87

Jones, G, 2002, The Youth Divide: Diverging paths to adulthood, York: Joseph Rowntree Foundation

Kawachi, I, Kennedy, BP, Wilkinson, RG, 1999, Crime: Social disorganization and relative deprivation, Social Science and Medicine 48, 6, 719-31

Kennedy, BP, Kawachi, I, Prothrow-Stith, D, Gibbs, B, Lochner, K, 1998, Social capital, income inequality and firearm violent crime, Social Science Medical Journal 47, 7-17

Kenway, P, Bushe, S, Tinson A, Born, TB, 2015, Monitoring poverty and social exclusion in Scotland 2015,York: Joseph Rowntree Foundation and New Policy Institute

Lanchester, J, 2013, Let's call it failure, London Review of Books 35, 1, 3-6

Lansley, S, Mack, J, 2015, Breadline Britain: The rise of mass poverty, London: Oneworld Publications

MacDonald, R, 2011, Youth transitions, unemployment and underemployment: Plus ça change, plus c'est la même chose?, Journal of Sociology 47, 4, 427-44 
MacDonald, R, Marsh, J, 2005, Disconnected youth? Growing up in Britain's poor neighbourhoods, London: Palgrave

MacInnes, T, Aldridge, H, Bushe, S, Kenway, P,Tinson, A, 2013, Monitoring poverty and social exclusion 2013, York: Joseph Rowntree Foundation and New Policy Institute

MacInnes, T, Aldridge, H, Bushe, S, Kenway P,Tinson, A, Born, TB, 2014, Monitoring poverty and social exclusion 2014, York: Joseph Rowntree Foundation and New Policy Institute

McKnight, A, Hills, J, 2015, The coalition's record on employment: Policy, spending and outcomes 2010-2015, CASE, Summary Working paper 15, http://sticerd.lse. ac.uk/dps/case/spcc/SWP15.pdf

Melrose, M, 2012,Young people, Welfare reform and social insecurity, Youth and Policy 108, March

Messner, SF, 1989, Economic discrimination and societal homicide rates: Further evidence on the cost of inequality, American Sociological Review 54, 597-611

Nilsson, A, Backman, O, Estrada, F, 2013, Involvement in crime, individual resources and structural constraints: Processes of cumulative (dis)advantage in a Stockholm birth cohort, British Journal of Criminology 53, 2, 297-318

Padley, M, Hirsch, D, 2013, Households below a minimum income standard: 2008/09 to 2010/11, programme paper,York: Joseph Rowntree Foundation

Pridemore, WA, 2011, Poverty matters: A reassessment of the inequality-homicide relationship in cross-national studies, British Journal of Criminology 51, 5, 739-72

Rutter, M, Giller, H, 1983, Juvenile delinquency: Trends and perspectives, London: The Gilford Press

Sampson, RJ, Laub, JH, 1993, Crime in the making: Pathways and turning points through life, London: Harvard University Press

Schmuecker, K, 2013, Recession pushes more young single people below minimum income standard,York: Joseph Rowntree Foundation

Schui, F, 2014, Austerity: The great failure, London:Yale University Press

Sissons, P, Jones K, 2012, Lost in transition? The changing labour market and young people not in employment, education or training, London: The Work Foundation

Skarðhamar, T, 2009, Family dissolution and children's criminal careers, European Journal of Criminology 6, 203-23

Sutherland, A, Brunton-Smith, I, Jackson, J, 2013, Collective efficacy, deprivation and violence in London, British Journal of Criminology 53, 1050-74

Thompson, H, 2014, The Thatcherite economic legacy, in S Farrall, C Hay (eds) The legacy of Thatcherism: Assessing and exploring Thatcherite social and economic policies, Oxford: Oxford University Press and the British Academy

Tittle, CR, 1983, Social class and criminal behavior: A critique of the theoretical foundation, Social Forces 62: 334-58

Tittle, CR, Meier, RF, 1990, Specifying the SES/delinquency relationship, Criminology $28,2,271-300$

Tittle, CR, Villemez, W, Smith, DA, 1978, The myth of social class and criminality: An empirical assessment of the empirical evidence, American Sociological Review 43, $5,643-56$

Tombs, R, 2014, The English and their history, London: Allen Lane

TUC, 2013, Welfare benefits: A necessity not a lifestyle choice, London:TUC

Tunstall, R, Lupton, R, Green, A, Watmough, S, Katie Bates, K, 2012, Disadvantaged young people looking for work: a job in itself? York: Joseph Rowntree Foundation 
Verbruggen, J, Blokland, AJ, van der Geest, VR, 2012, Effects of employment and unemployment on serious offending in a high-risk sample of men and women from ages 18 to 32 in the Netherlands, British Journal of Criminology 52, 5, 845-69

Vickerstaffe, SA, 2003,Apprenticeships in the 'golden age':Were youth transitions really smooth and unproblematic back then?, Work, Employment and Society 17, 2, 269-87

Wacquant, L, 2009, Punishing the poor: The Neoliberal government of social insecurity, London: Duke University Press

Walker, C, 2014, 'Don't cut down the tall poppies': Thatcherism and the strategy of inequality, in S Farrall, C Hay (eds) The legacy of Thatcherism: Assessing and exploring Thatcherite social and economic policies, Oxford: Oxford University Press and the British Academy

Watts, B, Fitzpatrick, S, Bramley, G, Watkins, D, 2014, Welfare sanctions and conditionality in the UK, York: Joseph Rowntree Foundation

Webster, C, Kingston, 2014a, Poverty and crime review, Joseph Rowntree Foundation: Anti-poverty strategies for the UK, full report,York: Joseph Rowntree Foundation, http://eprints.leedsbeckett.ac.uk/849/1/JRF\%20Final\%20Poverty\%20and\%20 Crime\%20Review\%20May\%202014.pdf

Webster, C, Kingston, S, 2014b, Poverty and crime, in Reducing poverty in the UK: A collection of evidence reviews, pp 148-152, York: Joseph Rowntree Foundation, www. jrf.org.uk/sites/files/jrf/Reducing-poverty-reviews-FULL_0.pdf

Willis, P, Bekenn, A, Ellis, T, Whitt, D, 1988, Social conditions of young people in Wolverhampton, Aldershot: Avebury

Wright, BRE, Caspi, A, Moffitt, TE, Miech, RA, Silva, PA, 1999, Reconsidering the relationship between SES and delinquency: Causation but not correlation, Criminology 37, 175-94 